\title{
Sosialisasi Gerakan Keluarga Sadar Obat: DAGUSIBU Pada Anggota Aisyiyah Kota Surakarta
}

\author{
1*Ambar Yunita Nugraheni, Ajeng Ganurmala, Kartika Putri Pamungkas \\ ${ }^{1}$ Fakultas Farmasi, Universitas Muhammadiyah Surakarta \\ *Penulis korespondensi, email: ayn122@ums.ac.id
}

(Received: 30 June 2020/Accepted: 5 July 2020/Published: 8 July 2020)

\begin{abstract}
Abstrak
Peningkatan swamedikasi (pengobatan sendiri) oleh masyarakat, berdampak terhadap terjadinya penyimpanan persediaan obat di rumah tangga. Hal tersebut diperlukan pengetahuan dalam pengelolaan obat yang tepat supaya tidak terjadi kesalahan dalam penggunaan obat. Untuk mengatasi masalah tersebut, kewajiban apoteker (farmasis) yaitu melakukan pendekatan terhadap masyarakat dengan memberikan informasi yang tepat terkait penggunaan obat yang benar mulai dari cara mendapatkan sampai dengan membuang obat yang sudah habis. Tujuan program Gerakan Keluarga Sadar Obat (GKSO) DAGUSIBU yaitu masyarakat menjadi lebih pintar dan bijak dalam menggunakan obat. Sosialisasi ini dilakukan di Ranting Aisyiah Kota Surakarta. Metode yang dilakukan melalui penyuluhan DAGUSIBU kepada anggota Aisyiah dilakukan dengan cara memberikan informasi langsung (presentasi) dan pemberian leaflet terkait DAGUSIBU. Hasil pretest menunjukkan bahwa sebagian besar peserta telah mengetahui bahwa obat sebaiknya didapatkan di apotek dan mengetahui ciri obat yang yang rusak. Pengetahuan yang kurang terdapat pada: penandaan obat, penggunaan obat sebelum dan setelah makan, penggunaan antibiotik, tempat penyimpanan obat dan waktu penyimpanan obat, cara membuang obat yang rusak. Berdasarkan pengamatan setelah dilakukan penyuluhan menunjukkan adanya respon yang baik terhadap pemahaman dalam mendapatkan, menggunakan, menyimpan dan membuang obat dengan tepat pada anggota Aisyiah.
\end{abstract}

Kata Kunci : DAGUSIBU, GKSO, obat

\begin{abstract}
Increased self-medication by the community has an impact on the occurrence of storage of drug supplies in the household. This requires knowledge in the management of appropriate drugs so that errors do not occur in the use of drugs. To overcome this problem, the obligation of pharmacists (pharmacists) is to approach the community by providing appropriate information related to the correct use of drugs ranging from how to get to disposing of drugs that have run out. The goal of the DAGUSIBU Drug Conscious Family (GKSO) Movement program is that people become smarter and wiser in using drugs. This socialization was carried out in Surakarta City's Aisyiah Branch. The method carried out through counseling DAGUSIBU to members of Aisyiah is done by providing direct information (presentations) and giving leaflets related to DAGUSIBU. The results of the pretest showed that most participants already knew that the drug should be obtained at the pharmacy and knew the characteristics of the damaged drug. Lack of knowledge on: drug marking, use of drugs before and after eating, use of antibiotics, storage of drugs and time to store drugs, how to get rid of damaged drugs. Based on observations after counseling showed a good response to understanding in getting, using, storing and disposing of drugs properly on Aisyiah members.
\end{abstract}

Keywords: DAGUSIBU, drugs, GKSO 


\section{Pendahuluan}

Meningkatnya sarana kesehatan (klinik dan apotek) di Surakarta berdampak pada penggunaan obat masyarakat yang secara bebas melakukan upaya untuk memelihara dan meningkatkan kesehatan sendiri (swamedikasi). Berdasarkan hasil Riset Kesehatan Dasar (RISKESDAS) tahun 2013, secara nasional proporsi rumah tangga yang menyimpan obat keras sebanyak $35,7 \%$ dan antibiotik $27,8 \%$ untuk swamedikasi (pengobatan sendiri). Sedangkan proporsi di Jawa Tengah sebanyak 31,9\%. Secara nasional 47,0\% rumah tangga menyimpan obat sisa (resep dokter dan obat yang tidak habis sebelumnya) dan 42,2\% menyimpan obat untuk persediaan. Sumber utama untuk mendapatkan obat yaitu dari apotek $(41,1 \%)$ dan toko obat/ warung $(37,2 \%)$. RISKESDAS (2013) juga menunjukkan bahwa sebagian besar $(85,9 \%)$ masyarakat di perkotaan maupun pedesaan tidak memiliki pengetahuan yang benar (pengetahuan rendah) tentang obat generik.

Berdasarkan beberapa penelitian menunjukkan bahwa tingkat pengetahuan masyarakat terhadap pengobatan sendiri (swamedikasi) dalam kategori cukup, akan tetapi ketepatan dalam pemilihan obat $>50 \%$ masih menunjukkan ketidakrasionalan terapi. Hal tersebut dikhawatirkan akan menyebabkan medication error dan meningkatnya resistensi terhadap antibiotik, sehingga diperlukan peningkatan pemberian informasi yang lebih kepada pasien ata masyarakat khususnya tentang penggunaan obat (Afif, 2015; Hantoro, 2014; Jihani, 2014). Kesalahan dalam terapi yang biasa terjadi pada masyarakat awam terkait obat yaitu penggunaan jenis obat yang sama dengan bentuk sediaan atau merek obat yang berbeda, hal tersebut dikarenakan semakin meningkatnya berbagai jenis sediaan dan jenis obat yang beredar. Untuk mengatasi masalah tersebut, kewajiban apoteker (farmasis) yaitu melakukan pendekatan terhadap masyarakat dengan memberikan informasi yang tepat terkait penggunaan obat yang benar mulai dari cara mendapatkan sampai dengan membuang obat yang sudah habis.

Program Gerakan Keluarga Sadar Obat (GKSO) DAGUSIBU mengharapkan masyarakat menjadi lebih pintar dan bijak dalam menggunakan obat. DAGUSIBU merupakan salah satu program untuk meningkatkan cara pengelolaan obat yang baik dan benar yaitu melalui informasi tentang bagaimana mendapatkan (DA), menggunakan (GU), menyimpan (SI) dan membuang (BU) obat dengan tepat. DAGUSIBU merupakan salah satu aplikasi dari kegiatan Gerakan Masyarakat Cerdas Menggunakan Obat (Gema Cermat) (Dewi, et al., 2019). Program DAGUSIBU sebelumnya telah diluncurkan oleh IAI, akan tetapi pemberian informasi tersebut hanya sekedar dengan pemasangan spanduk maupun poster yang bertuliskan DAGUSIBU di sarana kesehatan terutama apotek-apotek tanpa adanya pemberian informasi obat secara khusus dan langsung kepada pasien serta masyarakat (IAI, 2014). Program pemberian informasi tentang DAGUSIBU yang akan dilakukan bertujuan untuk meningkatkan pengetahuan masyarakat terkait penggunaan obat yang baik dan benar serta mengetahui kebutuhan informasi yang diperlukan masyarakat akan obat yang digunakan.

Berdasarkan survey diperoleh informasi bahwa anggota Aisyiah masih banyak yang menyimpan obat di rumah baik untuk stok persediaan maupun sisa obat dari dokter. Selain itu, beberapa anggota juga memiliki obat rutin untuk penyakit kronisnya. Tingginya penyimpanan obat di rumah dan kurangnya tingkat pengetahuan masyarakat di ranting Aisyiah mengenai penggunaan obat dapat menyebabkan kemungkinan terjadinya medication error dan meningkatnya ketidaktepatan terapi. Hasi survey juga menunjukkan bahwa sebagian besar masyarakat mendapatkan obat dari apotek dan toko obat/ warung dengan tujuan swamedikasi (pengobatan sendiri). Sehingga, diperlukan penyuluhan terkait pengelolaan obat yang baik dan benar dikenal dengan DAGUSIBU. Penyuluhan DAGUSIBU diharapkan masyarakat paham penggunaan obat yang baik dan benar sehingga tujuan pengobatan dan kualitas hidup dapat tercapai serta tidak menimbulkan tercemarnya lingkungan karena pembuangan limbah obat yang salah. 


\section{Metode}

Sosialisasi dilakukan pada anggota ranting Aisyiah Banyuanyar Kota Surakarta. Sosialisasi melalui penyuluhan menggunakan metode ceramah dan diskusi. Diskusi dilakukan dengan metode tanya jawab terkait materi serta konseling berdasarkan masalah setiap anggota terkait penggunaan obat. Materi selain disajikan melalui presentasi juga diberikan melalui leaflet terkait cara pengelolaan obat yang baik (DAGUSIBU), supaya anggota dapat mecermatinya. Materi penyulihan dan leaflet berisi tentang: cara mendapatkan obat yang benar berdasarkan penandaaan obat, cara menggunakan obat yang benar terkait aturan pakai dan berdasarkan jenis dan/ atau bentuk sediaan obat, cara menyimpan obat yang benar terkait tempat penyimpanan dan waktu atau lama penyimpanan obat, cara membuang obat terkait ciri obat rusak serta cara mebuang berdasarkan jenis dan/ atau bentuk sediaan obat. Pada penyuluhan ini juga dilakukan pretest untuk mengetahui gambaran kebutuhan informasi terkait pengelolaan obat yang diperlukan.

\section{Hasil dan Pembahasan}

Kegiatan pengabdian masyarakat melaluli sosialisasi DAGUSIBU pada anggota Aisiyah Kota Surakarta merupakan suatu aplikasi kegiatan yang mengikuti salah satu program promosi kesehatan Ikatan Apoteker Indonesia (IAI). Kegiatan penyuluhan DAGUSIBU merupakan suatu kegiatan para apoteker di seluruh Indonesia dengan tujuan untuk memberikan edukasi kepada masyarakat mengenai pentingnya memahami penggunaan obat dengan baik dan benar. Edukasi DAGUSIBU merupakan pemberian informasi terkait cara mendapatkan, menggunakan, menyimpan dan membuang obat dengan benar (IAI, 2014). Berdasarkan Dewi, et al (2019) bahwa kegiatan sosialisasi DAGUSIBU dapat meningkatkan pemahaman masyarakat sehingga meningkatkan kualitas hidup masyarakat.

Peningkatan penggunaan obat di masyarakat baik obat resep maupun non resep (swamedikasi/ obat yang dibeli sendiri tanpa resep dokter) perlu didukung dengan pengetahuan masyarakat yang baik tentang pengelolaan obat yang didapatkan agar terhindar dari efek yang tidak diinginkan. Sosialisasi ini diharapkan dapat membantu ibu-ibu anggota Aisiyah dalam pengelolaan obat baik di lingkungan keluarga maupun masyarakat secara umum. Kegiatan ini dilakukan pada waktu pertemuan rutin Aisyiah tiap minggu, dengan agenda penyuluhan kesehatan yang dilakukan tiap minggu ketiga. Peserta penyuluhan adalah ibu-ibu anggota Aisiyah Banyuanyar yang sebagian besar berusia 50-60 tahun. Peserta sosialisasi sebagian besar memiliki latar belakang pendidikan SLTA (Sekolah Lanjutan Tingkat Atas) dan sebagai ibu rumah tangga. Berdasarkan Prabandari and Febriyanti (2016), menunjukkan bahwa sasaran utama DAGUSIBU dilakukan pada kelompok geriatric karena sebagian besar mengalami penyakit kronis dan polipatologi.

Penyuluhan diawali dengan pengisian kuesioner tingkat pengetahuan terkait DAGUSIBU untuk memberikan gambaran terkait informasi yang diperlukan oleh paserta. Hasil pretest menunjukkan bahwa sebagian besar peserta telah mengetahui bahwa untuk mendapatkan obat sebaiknya di apotek dan ciri obat yang yang rusak. Pengetahuan yang kurang terdapat pada: penandaan obat, penggunaan obat sebelum dan setelah makan, penggunaan antibiotik, tempat penyimpanan obat dan waktu penyimpanan obat, cara membuang obat yang rusak.

Penyampaian materi inti dilakukan dengan mempresentasikan materi kepada peserta secara langsung serta membagikan materi dalam bentuk leaflet. Pemaparan materi dilakukan secara diskusi aktif. Pada penyuluhan ini juga digunakan alat peraga untuk membantu penyampaian materi yaitu dilakukan dengan cara menunjukkan beberapa contoh sediaan obat berdasarkan golongan obat (obat bebas, obat bebas terbatas, obat keras) serta simulasi cara penggunaan obat sediaan khusus (tetes mata). Berdasarkan Suryoputri and Sunarto (2019), menunjukkan bahwa edukasi DAGUSIBU obat dan simulasi cara penggunaan dan pengelolaan obat dapat meningkatkan pengetahuan masyarakat. 
Materi sosialisasi yang disampaikan pada penyeluhan ini meliputi:

a. Klasifikasi obat : obat bebas, obat bebas terbatas, obat keras serta obat wajib apotek.

Pada materi ini peserta diberikan contoh obat dari masing-masing golongan tersebut dan dijelaskan perbedaan macam obat tersebut serta menginformasikan cara untuk mendapatkan obat tersebut. Pemberian informasi ini diharapkan dapat mengetahui jenis obat yang boleh dan tidak boleh dibeli bebas tanpa resep dari dokter. Berdasarkan penelitian Jihani (Selain itu, memberikan contoh dampak yang kemungkinan dapat terjadi. Berdasarkan hasil pretest, menunjukkan bahwa sebagian besar anggota Aisyiah belum memahami tentang perbedaan logo obat bebas, bebas terbatas dan obat keras.

b. Penggunaan obat yang meliputi aturan pakai dan macam-macam bentuk sediaan obat serta cara penggunaannya.

Cara penggunaan obat merupakan poin penting yang harus diperhatikan dan dipahami sebelum menggunakan obat. Penggunaan obat yang salah akan menyebabkan suatu kejadian yang tidak diinginkan berupa medication error seperti kesalahan dosis sehingga terapi tidak efektif atau overdose. hal tersebut menyebabkan terapi menjadi tidak rasional (Depkes, 2008)

Obat dengan bentuk sediaan khusus (seperti: inhalasi/ obat hirup, suppositoria, tetes mata, tetes telinga, tetes hidung, insulin dan lainnya) perlu dipahami cara penggunaannya sebelum obat tersebut digunakan. Penggunaan obat sediaan khusus yang tidak tepat akan mengakibatkan efektivitas terapi kurang maksimal sehingga tujuan terapi bisa jadi tidak tercapai. Berdasarkan Lutfiyati, et al (2017), menunjukkan bahwa cara penggunaan obat penting untuk dijelaskan karena jika kurangnya informasi maka akan menyebabkan terjadinya kesalahan.

Berdasarkan hasil pretest menunjukkan bahwa pengetahuan terhadap makna dari aturan pakai obat (seperti $3 x$ sehari 1 tablet) sebagian besar peserta memahami, akan tetapi untuk takaran obat cair/ sirup seperti sendok teh dan sendok makan yang seharusnya $5 \mathrm{~mL}$ dan 15 $\mathrm{mL}$ belum dipahami. Cara konsumsi obat sebagian besar juga diketahui adalah setelah makan, serta untuk penggunaan antibiotik tidak perlu dihabiskan jika kondisi sudah membaik. Pengetahuan yang kurang sesuai dari masyarakat seperti tidak tepatnya cara penggunaan obat maka dapat menyebabkan efek terapi tidak maksimal dan bahwakan dapat memicu interaksi jika digunakan dengan obat lain maupun makanan karena tidak semua obat boleh digunakan setelah makan atau bersama makanan dan obat lain. Penggunaan antibiotik yang tidak tepat dapat meyebabkan pengobatan kurang efektif, peningkatan resiko keamanan pasien, peningkatan resistensi dan tingginya biaya pengobatan (PerMenkes, 2011)

c. Cara penyimpanan obat perlu diperhatikan untuk menjaga kualitas dan stabilitas obat yang digunakan. Penyimpanan obat yang tidak sesuai dengan standar suhu yang telah dituliskan di label obat maka akan mengakibatkan penurunan stabilitas obat yaitu menyebabkan obat menjadi rusak karena adanya degradasi zat aktif maupun adanya kontaminasi oleh partikel asing karena sterilitas. Penyimpanan yang kurang sesuai juga berpengaruh terhadap efektivitas terapi (Lutfiyati, et al., 2017; Pujiastuti and Kristiani, 2019)

Berdasarkan hasil prestest, didapatkan hasil bahwa sebagian peserta masih beranggapan bahwa obat sirup bisa disimpan dikulkas dan dapat digunakan lagi jika sakit. Hal tersebut tidak sesuai dengan cara penyimpanan obat yang tepat, karena sirup yang mengandung gula jika disimpan dikulkas maka akan terbentuk Kristal, sehingga stabilitas obat tersebut berubah. Hal lain yang perlu diperhatikan untuk penggunaan tetes mata yang merupakan suatu sediaan steril yaitu bahwa masyarakat beranggapan jika tetes mata yang sudah dibuka bisa digunakan terus menerus sampai sebelum expired date (ED). Penggunaan tetes mata yang demikian tersebut merupakan cara yang salah, seharusnya jika tetes mata 
tersebut sudah dibuka dan dalam waktu 1 bulan maka sudah tidak boleh digunakan kembali karena untuk tetes mata harus terjaga sterilitasnya.

d. Cara membuang obat yaitu meliputi mengenal ciri obat yang rusak dan cara pembuangan obat yang tepat. Berdasarkan hasil prestest didapatkan hasil bahwa sebagian besar peserta sudah mengetahui bahwa obat yang rusak salah satunya adalah obat yang expired date (ED), ciri lainnya adalah jika warna, bau dan rasa obat sudah berubah. Sedangkan untuk cara pembuangan obat, sebagian besar masyarakat melakukannya dengan cara hanya membuang langsung pada tempat sampah. Hal tersebut merupakan tindakan yang salah, karena jika obat tidak dibuang dengan tepat maka dapat menyebabkan suatu pencemaran lingkungan selain itu dapat dipergunakan lagi oleh oknum yang tidak bertanggung jawab sehingga obat dapat disalahgunakan. Cara pembuangan yang tepat yaitu dengan cara obat yang rusak sebelum dibuang seharusnya dikeluarkan dahulu dari wadah aslinya dan dihancurkan (sediaan padat digerus dan sediaan cair diencerkan), kemudian setelah itu baru dibuang ketempat sampah dengan wadah tertutup rapat (Lutfiyati, et al., 2017; Pujiastuti and Kristiani, 2019)

Harapan dari kegiatan sosialisasi DAGUSIBU ini yaitu masyarakat agar menjadi lebih memperhatikan dalam mendapatkan, menggunakan, menyimpan dan membuang obat dengan baik. Selain itu, masyarakat yang telah mendapatkan informasi DAGUSIBU dapat menerapkan cara pengelolaan obat baik khususnya di lingkungan keluarga dan dan dapat membagikan informasi tersebut kepada masyarakat pada umumnya.

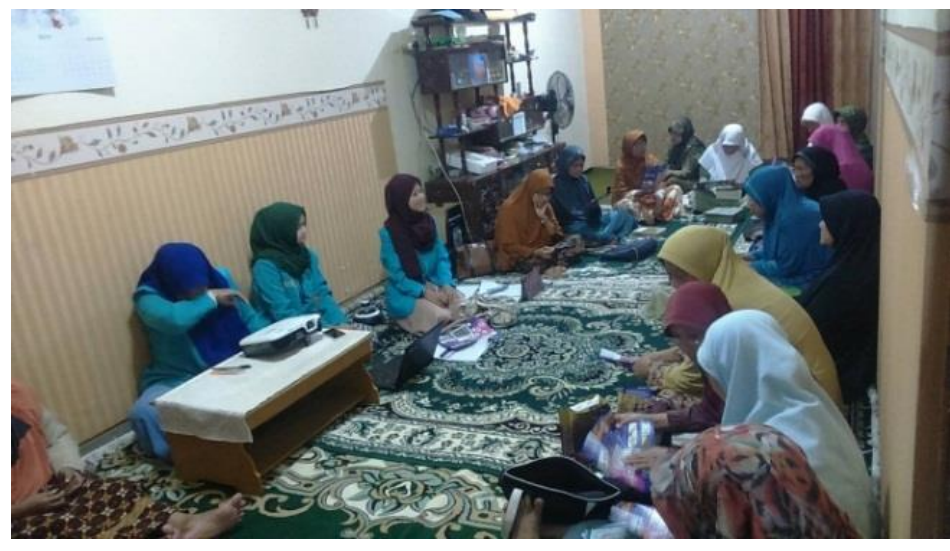

Gambar 1. Peserta mengisi pretest

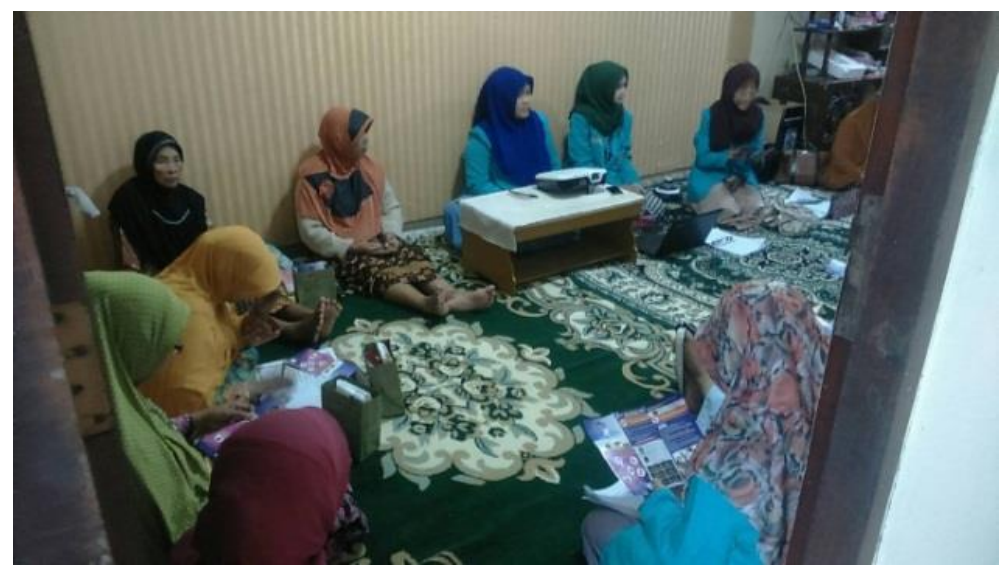

Gambar 2. Penyampaian materi 

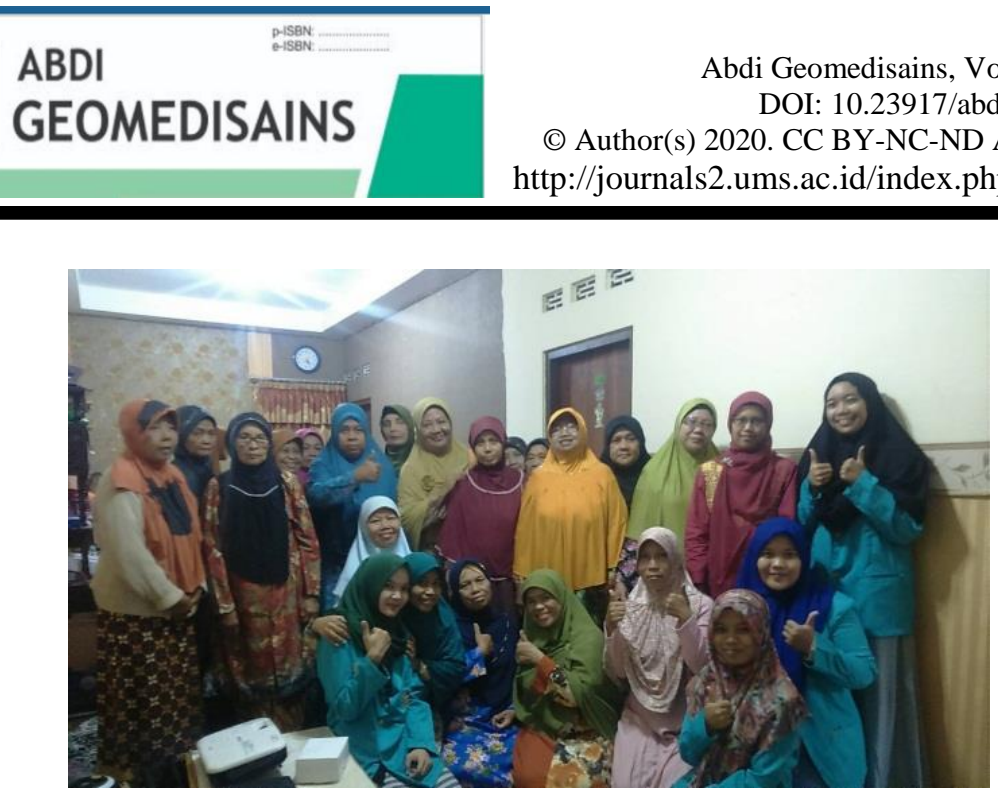

Gambar 3. Foto bersama dengan peserta

\section{Simpulan}

Hasil pretest menunjukkan bahwa sebagian besar peserta telah mengetahui bahwa obat sebaiknya didapatkan di apotek dan mengetahui ciri obat yang yang rusak. Pengetahuan yang kurang terdapat pada: penandaan obat, penggunaan obat sebelum dan setelah makan, penggunaan antibiotik, tempat penyimpanan obat dan waktu penyimpanan obat, cara membuang obat yang rusak. Berdasarkan pengamatan setelah dilakukan penyuluhan menunjukkan adanya respon yang baik terhadap pemahaman dalam mendapatkan, menggunakan, menyimpan dan membuang obat dengan tepat pada anggota Aisyiah.

\section{Persantunan}

Ucapan terima kasih kami berikan kepada: Universitas Muhammdiyah Surakarta yang telah mendukung terlaksananya program ini melalui PID (Pengembangan Individu Dosen) Pengabdian Kepada Masyarakat dan Pimpinan Ranting Aisyiah Kota Surakarta yang telah menyediakan tempat untuk terselenggaranya program penyuluhan ini.

\section{Referensi}

Afif, A. (2015). Hubungan Tingkat Pengetahuan dengan Ketepatan Penggunaan Obat Analgetik pada Swamedikasi Nyeri di Masyarakat kabpaten Demak. Skripsi. Fakultas Farmasi Universitas Muhammadiyah Surakarta

Depkes. (2008). Tanggung Jawab Apoteker Terhadap Keselamatan Pasien (Patient Safety). Direktorat Bina Farmasi Komunitas dan Klinik, Dirjen Farmalkes, Departemen Kesehatan Republik Indonesia

Dewi, A.P., Wardaniati, I., Pratiwi, D., Valzon, M. (2019). Sosialisasi Gerakan Masyarakat Cerdas enggunakan Obat di Desa Kumain Kecamatan Tandun Kabupaten Rokan Hulu. Jurnal Pengabdian Masyarakat Multidisiplin, Vol.3 No.1.

Hantoro, D.T., Pristianty, L., Athiyah, U., Yuda, A. (2014). Pengaruh Pengetahuan terhadap Perilaku Swamedikasi Obat Anti Inflamasi Nonsterpoid (AINS) Oral pada Etnis Arab di Surabaya. Jurnal farmasi Komunitas, Vol. 2, No. 2, 45-48

Jihani, M.A. (2014). Hubungan Pengetahuan dan Sikap pasien dengan Tindakan Membeli Obat Sendiri tanpa Resep Dokter (Swamedikasi) Antibiotik pada Apotek Swasta di Wilayah 
Kerja Puskesmas Mataram Tahun 2014. Skripsi. Fakultas Kesehatan Masyarakat Universitas Nusa Tenggara Barat

Lutfiyati, H., Yuliatuti, F., Dianita, P.S. (2017). Pemberdayaan Kader PKK dalam Penerapan DAGUSIBU (Dapatkan, Gunakan, Simpan, dan Buang) Obat dengan Baik dan Benar. The 6th University Research Colloquium. Universitas Muhammadiyah Magelang.

Ikatan Apoteker Indonesia. (2014). Pedoman Pelaksanaan Gerakan Keluarga Sadar Obat, Ikatan Apoteker Indonesia, Jakarta.

PerMenkes. (2011). Peraturan Menteri kesehatan Republik Indonesia Nomor 2406/Menkes/Per/XII/2011 Tentang Pedoman Umum Penggunaan Antibiotik. Jakarta

Prabandari, S., and Febriyanti, R. (2016). Sosialisasi Pengelolaan Obat DAGUSIBU (Dapatkan, Gunakan, SImpan, Buang) di kelurahan Pesurungan Kidul Kota Tegal Bersama Ikatan Apoteker Indonesia Tegal. Parapemikir Jurnal Ilmiah Farmasi, Vo. 5 No. 1

Pujiastuti, A., and Kristiani, M. (2019). Sosialisasi DAGUSIBU (Dapatkan, Gunakan, Simpan, Buang) Obat dengan Benar pada Guru dan Karyawan SMA Theresiana I Semarang. Indonesian Journal of Community Services, Volume 1, No.1, May 2019

RISKESDAS. (2013). Riset Kesehatan Dasar 2013. Badan Penelitian dan Pengembangan Kesehatan, Kementerian Kesehatan Republik Indonesia, 40-46

(C) 2020 by the authors. Submitted for possible open access publication under the terms and conditions of the Creative Commons Attribution (CC-BY-NC-ND) license (http://creativecommons.org/licenses/by/4.0/). 